\title{
$\widehat{A}$ Madridge \\ madridge Journal of Pharmaceutical Research \\ Interconnecting Scientific World
}

Research Article

Open Access

\section{Medicinal Plants as a Potential Source of Male Contraceptive Agents}

\author{
Jyoti Sethi ${ }^{1}$, Janardhan Singh ${ }^{2}$, Gurung $\mathbf{N}^{\mathbf{1}}$ and Aggarwal $\mathbf{A}^{\mathbf{1}}$ \\ ${ }^{\prime}$ Department of Physiology, Pt. B. D. Sharma Post Graduate Institute of Medical Sciences, Rohtak, Haryana, India \\ ${ }^{2}$ Department of Pharmacology, Pt. B. D. Sharma Post Graduate Institute of Medical Sciences, Rohtak, Haryana, India
}

\section{Article Info \\ *Corresponding author: \\ Jyoti Sethi \\ Professor \\ Department of Physiology \\ Pt. B. D. Sharma Post Graduate Institute of Medical Sciences \\ Rohtak \\ Haryana-124001 \\ India \\ E-mail: dr_jyotisethi@rediffmail.com}

Received: March 10, 2017

Accepted: April 11, 2017

Published: April 16, 2017

Citation: Sethi J, Singh J, Gurung N, Aggarwal A. Medicinal Plants as a Potential Source of Male Contraceptive Agents. Madridge J Pharm Res. 2017; 1(1): 7-12.

doi: 10.18689/mjpr-1000102

Copyright: @ 2017 The Author(s). This work is licensed under a Creative Commons Attribution 4.0 International License, which permits unrestricted use, distribution, and reproduction in any medium, provided the original work is properly cited.

Published by Madridge Publishers

\begin{abstract}
To control the population explosion in the world, new methods of contraception involving men is an attractive alternative. Since ancient times, plants and plant based products have been used as a valuable and safe natural source of medicines for treating various ailments. India possesses a vast reserve of medicinal plants which have been used extensively in the treatment of various diseases. The reversibility of antifertility effects of plants and its active components, play a major role in development of male contraceptive agents. The present review attempts to discuss medicinal effects of plant derived products on male reproductive system.
\end{abstract}

Keywords: Male contraception; Medicinal plants; Spermatogenesis; Antifertility effect; Testosterone.

\section{Introduction}

The world's population has risen to an alarming level especially in developing and underdeveloped countries and has detrimental effects on life supporting system [1]. Plants continue to be major source of medicines throughout human history. A wide majority of herbal plants possess pharmacological principles, which has rendered them useful as curative for numerous diseases. The World Health Organisation (WHO) reports that 70\%$80 \%$ of the world's population confide in traditional medicines for primary health care [2]. Therefore, exploring traditionally reported medicinal plants to liberate their potential for the betterment of human health is of paramount importance. Several plants are reported to exert toxic effects on male reproductive organs including testis, epididymis, accessory sex glands and associated hormones $[3,4]$. The present review highlights the plants and their products that can be used as potential male antifertility agents.

\section{Main Body}

Plants possessing antifertility activities include the following :-

Abrus precatorius Linn (Fabaceae) Eng-Indian Liquorice, Hindi- Gunchi, Rati. A climber found throughout India, upto an altitude of 1050 meters in the outer Himalayas. It's alcoholic seed extract given to sexually mature rats $(100 \mathrm{mg} / \mathrm{kg}$, p.o.) for 60 days resulted in significant lowering of sperm motility and sperm morphology (decapitation, acrosomal damage and formation of bulges on mid-piece region of sperm) [5]. Steroidal fraction of this seed injected in rats (30 mg i.m., alternating days for 20 days) caused testicular lesion manifesting in cessation of spermatogenesis [6]. A dose dependent testicular degeneration was observed with rats injected with (100, 200 and $300 \mathrm{mg}$ respectively) of steroidal fraction of seeds [7]. Ethanolic extract of air dried seed powder $(1 \mathrm{mg} / \mathrm{ml} /$ day, IP for 12 days) exhibited antispermatogenic activity in albino rats. 
Histology of testicular follicle showed degeneration and spermatogenic arrest, reduced leydig cells and shrunken seminiferous tubules [8]. Oral administration of $50 \%$ ethanolic extract of seed $(250 \mathrm{mg} / \mathrm{kg}$ ) for 30 days and 60 days induced a total infertility in male albino rats, a condition which however was reversible. Suppression of sperm motility was most pronounced effect of this treatment.

Aeacia auriculae formis A. Cunn ex.Benth (Minosaceae). Sperm immobilizing effects of mixture of the triterpene saponins acacia side $A$ and $B$ (obtained from this plant) have been studied in in-vitro. The lowest concentration (ED) required for immobilization of human sperm using a modified SanderCrammer test was found to be $0.35 \mathrm{mg} / \mathrm{ml}$. Compounds were more potent as compared to Tritonx -100 using the cervical mucus penetration test. The ED successfully prevented the sperm entry in the human cervical mucus. Electron microscopy revealed plasma membrane disintegration and dissolution of acrosomal cap of the sperm [9]. The $50 \%$ ethanolic extract of plant has been reported to have spermicidal activity. A sinuatathe saponin (acacic acid) obtained from the bark was also found to exhibit spermicidal activity against human spermatozoa. Its maximum activity was observed at $0.04 \%$ dilution.

Aegle marmelos Linn (Rutaceae) Eng-Bael tree, HindiBael. A moderate size slender tree, growing wildly throughout the deciduous forest of India up to an altitude of 1200 meters in height. Administration of ethanolic extract of its leaves in rats $(25$ and $50 \mathrm{ml} / \mathrm{kg}$, p.o.) for 30 days led to significant decrease in weight of testis, reduced sperm count, decreased sperm motility and decrease in both protein and RNA content of testis [10].

Aeschynomene indica Linn (Fabaceae) Eng- Hard Sola, Hindi- Laugauni

An erect, slender, shrubby, annual found throughout India. It ascends up to 1500 meters in foot hills and in Andaman Islands. Fifty percentethanolic extract (in $2 \%$ concentration invitro) has been reported to possess spermicidal activity against both rat and human spermatozoa [11].

Agave cantala (Haw) (Agaraceae) Eng- Bombay aloe. A perennial stout scapigerous plant with short woody stem native to Mexico.Ethanolic extract (2\%) of its rhizome and its spirostomal constituents has shown to possess spermicidal activity against human spermatozoa [12].

Aesandra butyracea (Roxb) sapotaceaeEng- Hill mahua, Indian-Butter tree, Hindi - Phalwara. Large deciduous tree found in the sub-Himalayan tract from Gharwal to Bhutan up to an altitude of 1500 meters and in Andaman Islands. Bassicacid, asapogenin isolated from the seeds has been reported to possess some spermicidal activity against human semen [13].

Albizia chinensis (Osbeck) Mimosaceae, Hindi- siran. A large deciduous tree distributed throughout the subHimalayan valleys up to 1200 meters altitude. They are found in Assam, West Bengal, Bihar, South India and Andaman. Ethanolic extract of bark and its triterpenic constituents possess spermicidal activity against human spermatozoa. Oleanolic acid, echinocystic acid and its two echinocystcic acid based saponins led to complete immobilization of human spermatozoa at $0.5,0.09,0.008$ and $0.006 \%$ concentrations, respectively [14].

A. lebbeck (Linn)-Ethanolic extracts of its pods and root at a concentration of $2 \%$ as well as saponinlebbekanin $E$ exhibited spermicidal activity in rat and human semen [15].

Allium sativum Linn (Alliaceae) Eng- Garlic, HindiLahsan. A hardy perennial herb is cultivated all over India. Chronic administration of garlic powder (50 mg for 70 days) resulted in inhibition of spermatogenesis in albino rats. Reduced concentration of sialic acid in testis, epididymis and seminal vesicle with decreased Leydig cells function reflected antiandrogenic nature of garlic [16].

Aloe vera Linn (Liliaceae) Eng- Indian aloe HindiGheekanwar. A coarse looking perennial herb with a short stem and fleshy leaves, found wild in many parts of the country but now widely cultivated. Aloin, a glycoside isolated from its leaves was given to Presbytislangurs ( $62.5 \mathrm{mg} /$ day, p.o.) for 120 days. A significant reduction was observed in spermatid cells (33.68\%), semniferous tubules and leydig cells was observed [17].

Anagallis arvensis Linn (Primulaceae) Eng- Blue Pimpernel Hindi- Joukumari Krishna Neel. A small much branched annual herb found over the greater parts of India that growup to an altitude of 2400 meters in the hills. Anagalligenone, the sapogenin isolated from the plant, revealed spermicidal activity in human semen at a concentration of $0.008 \%$ [13].

Andrographis paniculata (Burm f) Acanthaceae) EngThe creat, Hindi- Kalmegh. An erect annual herb found in the plains throughout India. Supplementation of dry leaf powder to male rats ( $20 \mathrm{mg} /$ day, p.o.) for 60 days resulted in cessation of spermatogenesis, degenerative changes in semiferous tubules, epididymis, seminal vesicle and leydig cells. Results suggested anti-spermatogenic and/ or an anti androgenic effect of the plant [18].

Anethum sowa Roxb (Apiaceae) Eng- Indian Dill, HindiSowa. An annual aromatic herb cultivated throughout India mainly in Punjab, UttarPradesh, Gujarat, Assam, Maharashtra and West Bengal. Volatile oil was tested for its spermicidal activity in the ejaculated human spermatozoa in vitro. At a dilution of 1:10 the oil exhibited spermicidal activity, in just 30 seconds [19].

Anisomeles malabarica Linn (Lamiaceae) Eng- Malabar. A densely pubescent, perennial herb commonly found in the western ghats from Maharashtra to Karnataka and Andhra Pradesh, Kerala and Tamil Nadu. Spermicidal activity in rat was observed with $5 \%$ ethanolic extract and in human semen at $2 \%$ concentration [11].

Ardisia thyrsiflora D. Don (Myrsinaceae). The $50 \%$ ethanolic extract of this plant (in vitro) showed spermicidal activity in male albino rat and human semen. The saponinsardisioside $A$ and $B$ isolated from $n$-butanol extract were reported to kill the human spermatozoa at $0.1 \%$ concentration [20].

Argemone mexicana Linn (Papaveraceae) Eng- Mexican poppy, Hindi- Piladhatura. An erect prickly annual herb naturalized throughout India up to an altitude of 1500 meters 
in height. Three isoquinone alkaloids from its seeds (dihydropalmatine hydroxide I, berberine II, protopine III) given to male dogs ( $30 \mathrm{mg} / \mathrm{kg}$ for 70 days) resulted in inhibition of spermatogenesis at the stage XII of late spermatids. Tests showed spermatids and leydig cells were also decreased [21].

Aristolochia indica Linn (Aristolochiaceae) Eng- Indian birthwort, Hindi- Isarmul. A perennial climber present throughout India in plains and lower hills. In adult male rats, administration of p-coumaric acid ( $50 \mathrm{mg} / \mathrm{kg}$, p.o. for 56 days) produced loss of libido and decrease in weight of testis [22].

Asparagus aofficinalis Linn (Asparagaceae) HindiHalyun. An erect widely branched perennial, native to temperate Europe and West Asia and is often grown in India. The spirost and glycosides obtained from methanolic extract of its fruits led to $100 \%$ immobolization of human spermatozoa at $1.5 \%$ concentration [23]. A. Plumosus- 2-yamogenin and 2-furostanol glycosides isolated from the alcoholic extract of root caused $100 \%$ immobilization of human spermatozoa at $1 \%$ and $1.5 \%$, levels respectively [24].

Azadirachta indica $\boldsymbol{A}$ Juss (Meliceae) Eng- margosa tree, Hindi- Neem. A large evergreen tree commonly found throughout India and is often cultivated. Spermicidal activity of nimbidinate has been studied in vitro in male rats and human semen. Neem oil exhibited strong spermicidal activity (within 30 second) in in vitro studies in Rhesus monkey and human spermatozoa [25]. Anti-fertility activity of the plant has also been reviewed by Hussain and Shiva Reddy in 1999 [26].

Barleria prionitis Linn (Acanthaceae) Hindi- sahacara. A small branched, spiny shrub found growing throughout hotter parts of India. Oral administration of root extract to male rats (100mg/day for 60 days) led to reduced spermatogenesis. Spermatids production decreased by $73.6 \%$. The extract reduced the fertility of male rats by $100 \%$. Numbers of sertoli cells and mature leydig cells were also found reduced (36.9\%) [27].

Berberis chitria Lindl (Berberidaceae). A large shrub distributed in Himalayas from Kashmir to Bhutan thatgrow to an altitude of 1800-3000 meters. Palmitive hydroxide isolated from roots of this plant when given to male dogs $(30 \mathrm{mg} / \mathrm{kg} /$ day) for 60 days resulted in impairment of primary and secondary spermatocytes and elongated spermatids (stages IV-VIII). Primary and secondary spermatocytes were reduced by $60 \%$ and $68 \%$, respectively. Anti-spermatogenic action of palmitive hydroxide might be mediated by disturbances in Leydig cell function [28].

Blighia sapida Koen (sapindaceae) Eng- Akee tree. A medium-sized tree occasionally cultivated in some parts of Maharashtra, West Bengal and Tamil Nadu. Saponins having hederagenin and oleanolic acid as sapogenin and glucose, rhamnose, arabinose and xylose as sugars, isolated from fruits were reported to have spermicidal action in human semen [13].

Calendula officinalis Linn (Asteraceae) Eng- Garden marigold, Hindi- Zergul. An aromatic erect herb native to Southern Europe commonly cultivated in Indian gardens. The $50 \%$ ethanolic extract of plant showed spermicidal activity in rats at $2 \%$ concentration [11].
Calotropis procera (Ait) Asclepiadaceae) Eng- Madar tree, Hindi- Madar. A small erect and compact shrub found throughout India up to an altitude of 1050 meters in height. Oral administration of flower and root extracts $(20 \mathrm{mg}$ for alternating days $x 30$ days) to desert male gerbils (Meriones Hurrianae) revealed testicular necrosis, degeneration of spermatogonia, spermatocytes and sertoli cells [29]. Calotropin administered to gerbils ( $25 \mathrm{mg} / \mathrm{kg}$ ) and rabbits ( 25 $\mathrm{mg} / \mathrm{kg} /$ day) for 30 days inhibited spermatogenesis. The population of spermatids was decreased by $65 \%$ and $95 \%$ in gerbils and rabbits respectively [30].

Caltha palustris Linn (Ranunculaceae) Eng- Marsh Marigold. A highly variable polymorphic aquatic herb found in the marshes throughout the Himalayas from Kashmir to Sikkim that grow to an altitude of 5000 meters in height. Butanol soluble fraction and ethanol extract of plant revealed in vitro spermicidal activity in human serum. Ethanol extract ( $2 \%$ concentration) has been observed to possess spermicidal activity in rat and human semen [11].

Canscora decussate (Roxb) Gentianaceae. Hindi- Sankhaphuli. A slender, erect, somewhat flaccid annual distributed throughout India in damp locations. Spermicidal activity of fraction I and II isolated from alcohol and aqueous extracts were studied in vitro on human semen and rat sperm. Minimum concentrations of fraction I and II was found to kill rat sperms within 5 minutes at levels of 1:50000 and 1:200, respectively. Furthermore, aqueous extract provided an effective male antifertility agent when given to male rats for 30 days [31].

Carica papaya Linn (Caricaceae) Eng- Papaya HindiPapita. Papaya was introduced into India in the 16th century and now it is widely cultivated throughout India. A number of studies have reported antifertility action of seeds of papaya (20 mg/rat/day) on administration for 8 weeks. Aqueous, alcoholic and chloroform extracts of seeds affecting sperm motility in rats has been noted. In male rabbits and langur monkeys, chloroform seed extracts (20-50 mg/day X 150 days) administration led to azoospermia and oligospermia [32].

Casearia tomentosa Roxb (flacourtiaceae) Hindi- Chilla. A shrub/tree found throughout India, up to an altitude of 900 meters in the hills and Andaman Islands. Administration of $50 \%$ ethanolic extract of leaves in male rats $(100 \mathrm{mg} / \mathrm{kg}$, p.o. for 21 days) exhibited significant antifertility activity [33].

Catharanthus roseus Linn (Apocynaceae) EngMadagascar Periwinkle Hindi- Sadabahar. An erect perennial herb, native to Malagasy is also commonly grown in gardens throughout India. Aqueous and alcoholic extracts of leaves have demonstrated anti-androgenic and antifertility effects in male albino rats [34].

Celastrus paniculatus willd (Celastraceae) Eng- Black oil plant, Hindi- Malkangani. A large woody climbing shrub distributed almost all over India that grow up to an altitude of 1800 meters in height. Supplementation of seed oil given in rats $(0.2 \mathrm{ml} / \mathrm{rat}$ for 30 days $)$ showed an anti-spermatogenic effect. The oily extract from seeds also led to vacuolization, germ cell depletion and arrested spermatogenesis in testis of rats [35]. 
Centratherum anthelminticum Linn (Asteraceae) HindiSomraj. A tall, leafy, annual herb distributed throughout India that grow up to 1677 meters in the Himalayas and Khasia hills. The seed extract has been reported to have spermicidal activity in rats but not such activity in human beings [11].

Cheiranthus cheiri Linn (Brassicaceae) Eng- Gilli, HindiTodri-Surkh. An erect or ascending perennial herb native to southern Europe. It is sometimes cultivated in gardens in northern and western India. Oral administration of Kaemopferol ( $250 \mathrm{mg} / \mathrm{kg} /$ day $\times 60$ days), a compound isolated from the herb's stem, induced antifertility (71\%) in male rats [36].

Cichorium intybus Linn (Asteraceae) Eng- Chicory HindiHinduba. An erect perennial herb native to temperate parts of the world and is found wild in Punjab and Andhra Pradesh. It is often cultivated in Bihar, Himachal, Assam, Maharashtra, Gujarat, Tamil Nadu, Orissa, Andhra Pradesh and Kerala. Chicory dry root powder extracted from the herb and administered to mice $(8.7 \mathrm{~g} / \mathrm{kg} \times 10$ days) demonstrated impairment of spermatogenesis [37].

Cinnamomum zeylanicum Nees (Lauraceae) Eng- Cinnamon Hindi- Dalchini. A moderate sized tree, native to Sri Lanka and cultivated in southern India. The oil of cinnamon has demonstrated in vitro spermicidal activity against human spermatozoa at a dilution of 1:400 [19].

Citrullus colocynthis Linn (Cucurbitaceae) Eng- Indian wild Gourd Hindi- Indrayan. Ascabrid perennial with prostrate or climbing angular stems and bifid tendrils found in warm, arid and sandy parts throughout India. The 50\% ethanol extract of its root administered at various concentration (50, 100 and $200 \mathrm{mg} / \mathrm{kg} /$ day p.o. for 60 days) to male rats showed decreased sperm motility, density and spermatogenesis arrest. A marked reduction in serum testosterone was also observed in all treatment groups [38].

Clerodendrum serratum Linn (Verbenaceae) HindiBharangi. A blue flowered shrub widely distributed throughout India. The $50 \%$ ethanolic extract of the plant demonstrated in vitro spermicidal activity in rat and human semen [11]. An $\mathrm{N}$-butanol fraction of $50 \%$ ethanolic extracts of the plant also exhibited in vitro spermicidal activity in humans.

Clinopodium umbrosum (BiebLabiataeceae) Eng-Catmint, Hindi-Janglipudina. A slender, pubescent, profusely branched herb distributed in the Himalayas from Kashmir to Bhutan, Andhra Pradesh, Khassi hills and throughout the hills of peninsular India. The $50 \%$ ethanolic extract of the plant has been reported to possess spermicidal activity in rat semen in vitro [11].

Colebrookia oppositifolia Smith (Lamiaceae) HindiBindaPansra. A densely tomentose hoary, widely branched shrub or small tree found throughout the hilly areas of India. Supplementation of ethanolic extract of its leavesin rats at different concentrations (100, $200 \mathrm{mg} / \mathrm{kg}$ p.o.) for 10 weeks significantly decreased the weight of testis and epididymis and reduction in spermatogenesis in rats. Reduction in sperm motility and count resulted in $100 \%$ infertility in rats by $200 \mathrm{mg} / \mathrm{kg}$ of ethanol extract [39].
Cotula hemisphaerica (Roxb) Asteraceae. An annual prostrate or erect herb that grows upto a height of 800 meters, found in Indo-gangetic plain, UP, Bihar, West Bengal, Assam, Manipur and Meghalaya. The ethanolic extract (50\%) of the plant has been demonstrated to possess spermicidal activity in rats [40].

Deeringia amaranthoides (Lamk) Amaranthaceae. Hindi- Latman. A climbing shrub found in the sub-Himalayan tracts from Chenab to Bhutan, Bihar, west Bengal and Assam. The $50 \%$ ethanolic extract of plant revealed spermicidal activity in rats in vitro. Ethanolic extract of its fruits (1\%) also showed spermicidal activity against rats and human spermatozoa [41].

Derris indica (Lank) Fabaceae. Eng- Pongam oil tree Hindi- Karaj. A medium-sized, glabrous tree found almost that grows upto an altitude of 1200 meters in height. Seed oil has been reported to produce strong spermicidal activity. Motility of sperm from healthy men was completely lost (0.2\%) within 20 seconds in presence of its three oil [42].

Dimeria gracilis Nees (Poaceae). A perennial stout grass found in Tamil Nadu and Karnataka. The 50\% aqueous ethanolic extract possess strong spermicidal activity against rat and human spermatozoa (2\% concentration) in vitro [43].

Diploknema butyracea (Roxb) Sapotaceae.Eng - Indian Butter tree, Hindi- Phulwara. A large deciduous tree commonly found in sub-Himalayan tracts from Uttrakhand east wards to Sikkim, Bhutan and the Andaman Islands. The sapogenin (bassic acid) obtained from seeds has exhibited spermicidal activity against human spermatozoa. Its maximum activity was observed at $0.006 \%$ dilution [44].

\section{Miscellaneous}

Sarcostemma acidum- Methanol extract $(100 \mathrm{mg})$ when administrated to male albino rats for 60 days, caused a decrease in the number of mature leydig cells and an increase in degeneration of leydig cells [45].

Martynia annu- Ethanol extract (100 mg, $200 \mathrm{mg} / \mathrm{kg}$ ) administrated for 60 days resulted in Leydig cell atrophy and reduction in serum concentration of $\mathrm{LH}$ and testosterone [46].

Leptadenia hastate Decne- Aqueous extract of leaf and stem has been reported to reduce velocity, linearity and sperm motility of male wistar rats [47]. Leydig cell nuclear area and mature leydig cells numbers were also significantly reduced on oral administration of $70 \%$ methanol extract of Tinospora cardifolia stem to male rats ( $100 \mathrm{mg} /$ rat for 60 days) [48].

Mentha piperita labialae $(20 \mathrm{mg} / \mathrm{L}$ ) and Mentha spicata labiatae (20 mg/L)- These herbal teas when fed to wistar rats increased serum FSH and $\mathrm{LH}$ levels and decreased total testosterone levels [49]. Administration of ethanol extracts of Colebrookea oppositifolia (200 mg, p.o. for 8-10 weeks) was associated with a decrease in the nuclear and cytoplasmic surface area of Leydig cells [50]. 


\section{Conclusion}

Keeping in view of the above discussion, medicinal plants can be used as effective anti-fertility agents, especially considering their effects on male reproductive physiology. Isolation and characterization of pharmacologically active compounds, safety, quality, efficacy of plant preparations are key issues, all of which need to be addressed before developing a potential herbal male contraceptive agent.

\section{References}

1. Ogbuewu IP, Unamba-oparah IC, Odoemenem VU, Etuk IF, Okoli TC. The potentiality of medicinal plants as the source of new contraceptive principles in males. N Am J Med Sci. 2011; 3(6): 255-63. doi: 10.4297/ najms.2011.3250

2. Kirtikar KR, Basu BD. In: Indian medicinal plants. Singh B, Singh MB editors. New Canaught place, Dehradun India. 1975; 785-788

3. Mali PC, Ansari AS, Chaturvedi M. Antifertility effect of chronically administered Martyniaannua root extract on male rats. J Ethnopharmacol. 2002; 82: 61-67. doi: 10.1016/SO378-8741(02)00084-3

4. D' Cruz SC, Vaithinathan S, Jubendradass R, Mathur PP. Effect of plants and plant products on the testis. Asian J Androl. 2010; 12:468-79. doi: 10.1038/aja.2010.43

5. Rao MV. Antifertility effects of alcoholic seed extract of Abrusprecartorious Linn in male albino rats. Acta Eur Fertil. 1987; 18: 217-20. PMID: 3439410

6. Bajaj A, Mathur RS, Wadhwa M, Bahel A. Effect of steroidal fraction of Abrusprecartoriouson testis of albino rats. Geobios. 1981; 8: 29-31

7. Sinha $S$, Mathur RS. Effect of steroidal fraction of seeds of Abrusprecartorius Linn on rat testis. Indian J Exp Biol. 1990; 28: 752-56. PMID: 2253968

8. Sharma DK, Verma MS. Antispermatogenic activity of Abrusprecatorious (Linn) seed extract in white albino rat. Indian Med J. 1987; 81:157-60

9. Pakrashi A, Ray H, Pal BC, Mahato SB. Sperm immobilizing effect of triterpenesaponins from Acacia auriculiformis. Contraception. 1991; 43:475-83. PMID: 1914460

10. Sur T K, Pandit S, Pramanik T. Antispermatogenic activity of leaves of AeglemarmelosCorr in albino rats: a preliminary report: Biomed. 1999; 19:19-202

11. Setty BS, Kamboj VP, Khanna NM. Screening of Indian plants for biological activity. Part VII. Spermicidal activity of Indian Plants. Indian $\mathrm{J}$ Exp Biol. 1977; Mar; 15(3): 231-2. PMID: 914327

12. Pant G. On the spermicidal activity of the constituents of rhizomes of Agave Cantala. Fitoterapia. 1988; 59: 340-1

13. Banerji R, Srivastava AK, Misra G, Nigam SK, Singh S, et al. Steroids and triterpenoidsaponins as spermicidal agents. Indian drugs. 1979; 17: 6-8

14. Rawa MSM, Negi DS, Pant G, Panwar MS. Spermicidal activity and chemical investigation of Albiziachinensis.Fitoterapia. 1989; 60: 168-9

15. Varshney IP, Vyas P, Srivastava HC, Singh PP. Study of AlbizzialebbeckBenth wood saponinlebbekanin E. Natl Acad Sci Lett (India). 1979; 2:135-6

16. Dixit $V \mathrm{P}$, Joshi $\mathrm{S}$. Effects of chronic administration of garlic (Allium sativum Linn) on testicular function. Indian J Exp Biol. 1982 Jul; 20(7): 534-6. PMID: 7173985

17. Gupta RS, Dixit VP. Antispermatogenic effects of aloin $\left(\mathrm{C}_{21} \mathrm{H}_{22} \mathrm{O}_{9}\right)$ in presbytislangure with special reference to Leydig Cell and testicular cell population dynamics. Indian Biol. 1991; 23: 33-38

18. Akbarsha MA, Monivannan B, Hamid KS, Vijayan B. Antifertility effect of graphispaniculata (Nees) in male albino rats. Indian J Exp Biol. 1990 May; 28(5): $421-6$

19. Buch JG, Dixit R K, Mansuri SM. Effect of certain volatile oils on ejaculated human spermatozoa. Indian J Med Res. 1988; 87: 361-3. PMID: 3169889
20. Malviya N, Pal R, Khanna NM, Chemical examination of Ardisianeriifolia wall. Indian J Chem. 1989; 28(6): 522-3

21. Gupta RS, Dixit VP, Dobhal MP. Antifertility studies of Isoquinoline alkaloids with special emphasis of structure activity relationships. Fitoteraopia. 1990; 61: 67-71

22. Pakrashi A, Kabir A, Ray A. 3-(4-hydroxyphenyl)-2-Propenoic acid - a reproductive inhibitor in male mice. Contraception. 1981; 23:677-86

23. Pant G, Panwar MS, Negi DS, Rawat MSM, Morris GA. Spirostanolglucoside from fruits of Asparagus officinalis. Phytochemistry. 1988; 27: 3324-5. doi: 10.1016/0031-9422(88)80057-8

24. Pant G, Panwar MS, Negi DS, Zagorski M. Steroidal glycosides from Asparagus plumosus baker. Herba Polonica. 1988; 34:175-81

25. Hussain MA, Shiva Reddy N. Neem in birth control. Indian For. 1999; 125; 743-44

26. Sinha KC, Riar SS. Neem oil- an ideal contraceptive. Biol Mem. 1985; 10(1\&2): 107-14

27. Gupta RS, Kumar P, Dixit VP, Dobhal MP. Antifertility studies of the root extract of the Barleriaprionitis Linn in male albino rats with special reference to testicular cell population dynamics.J Ethnophramacol. 2000 May; 70(2): 111-7. PMID: 10771200

28. Gupta RS, Dixit VP. Testicular cell population dynamics following Palmitine hydroxide treatment in male dogs. J Ethnopharmacol. 1989; 25: 151-7. PMID: 2747249

29. Garg SP, Bhushan R, Mehta R, Jain VM. A survey for alkaloids in Rajasthan desert plansts. Trans Isdt Ucds. 1980; 5(2): 62-4

30. Gupta RS, Sharma N, Dixit VP. Calotropin- A novel compound for fertility control. Ancient Sci Life. 1990; 9(4): 224-30

31. Tyagi $S D$, Agarwal SC. An ayurvedic product may be family planning agent through male. J Nat Integrat Med Ass. 1990; 32(5): 7-9

32. Lohiya NK, Manivannan B, Mishra PK, S et al. Choloform extract of Carica papaya seeds induces long term reversible azoospermia in Langur monkey. Asian J Androl. 2002 Mar; 4(1): 17-26. PMID: 11907624

33. Choudhary DN, Singh JN, Verma SK, Singh BP. Antifertility effects of leaf extracts of some plants in male rats. Indian J Exp Biol. 1990; 28(8): 714-6

34. Murugavel T, Akbarsha MA. Antispermatogenic effect of Vincarosea Linn. Indian J Exp Biol. 1991 Sep; 29(9): 810-2

35. Bidwai PP, Wangoo D, Bhullar N. Antispermatogenic action of Celastruspaniculatus seed extract in the rats with reversible changes in the liver. J Ethnopharmacol. 1990; 28(3): 293-303

36. Kumar P, Dixit VP, Khanna P. Antifertility studies of kaempferol: isolation and identification from tissue culture of some medicinally important plant species. Plantes medicinales et phytotherapie. 1989; 23: 193-201

37. Roy-Choudhary A, Venkatakrishna-Bhatt H. Spermatogenic inhibition by Cichoriumintybusaqeous root suspension in mice. Naturwissenschaften 1983;70(7): 365-6

38. Mali PC, Chaturvedi M, Ansari AS, Dixit VP. Antispermatogenic effects of an ethanol extract of Citrulluscolocynthis root in male albino rats. Pharm Biol. 2001; 39(2): 113-9. doi: 10.1076/phbi.39.2.113.6259

39. Gupta RS, Yadav RK, Dixit VP, Dobhal MP. Antifertility studies of Colebrookiaoppositifolia leaf extract in male rats with special reference to testicular cell population dynamics. Fitoterapia. 2001 Mar; 72(3): 23645. PMID: 11295299

40. Dhawan BN, Dubey MP, Mehrotra BN, Rastogi RP, Tandon JS. Screening of Indian Plants for biological activity: Part IX. Indian J Exp Biol. 1980 Jun 18(6): 594-606

41. Uniyal SK, Bahuguna S, Sati OP. Biological screening of extracts of some medicinal plants from Garhwal. Herba Hungarica. 1990; 29:37-41

42. Bandivdekar AH, Moodbidri SB. Spermicidal activity of seed oil of Pongamiaglabra. Arch Androl. 2002 Jan-Feb; 48(1): 9-13. PMID: 11789687

43. Bhatt BP, Panwar MS. Plants with fertility regulating potential of Garhwal Himalayas. Journal of Economic Botany and Phytochemistry. 1990; 2(1): 33-4 
44. Banerji R, Srivastava AK, Misra G, Nigam SK, Singh S et al. Steroid and triterpenoidsaponins as spermicidal agents. Indian Drugs. 1979; 17(1): 6-8

45. Venma PK, Sharma A, Mathur A, Sharma P, Gupta RS et al. Effect of Sarcostemmaacidum stem extract on spermatogenesis in male albino rats. Asian J Androl. 2002 Mar; 4(1): 43-7. PMID: 11907627

46. Mali PC, Ansari AS, Chaturvedi M. Antifertility effect of chronically administered Martyniaannua root extract on male rats. J Ethnopharmacol. 2002 Oct; 82(2-3): 61-7. PMID: 12241978

47. Bayala B, Telefo PB, Bassole IHN, Tamboura HH, Belemtougri RG et al. Antispermatogenic activity of Leptadenia hastate (Pers.) decne leaf stems aqueous extracts in male wistar rats. J Pharmacol Toxicol. 2011. 6(4): 391-399. doi: 10.3923/jpt.2011.391-399
48. Gupta RS, Sharma A. Antifertility effect of Tinosporacordifolia (willd.) stem extract in male rats. Indian J Exp Biol. 2003 Aug; 41(8): 885-9. PMID: 15248490

49. Akdogan M, Ozguner M, Kocak A, Oncu M, Cicek E. Effects of peppermint teas on plasma testosterone, follicle stimulating hormone and Luteinizing hormone levels and testicular tissue in rats. Urology. 2004; 64(2): 394-8. doi:10.1016/j.urology.2004.03.046

50. Gupta RS, Yadav RK, Dixit VP, Dobhal MP. Antifertility studies of Colebrookiaoppositifolia leaf extract in male rats with special reference to testicular cell population dynamics. Fitoterapia. 2001 Mar; 72(3): 23645. PMID: 11295299 